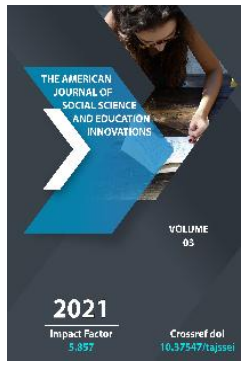

Journal Website: http://theamericanjour nals.com/index.php/taj ssei

Copyright: Original content from this work may be used under the terms of the creative commons attributes 4.0 licence.

\section{Theoretical And Methodological Basis Of Researching The Issue Of The Place And Role Of Women Of Uzbekistan In Cultural And Educational Processes (On The Example Of The XX Century)}

\author{
Nilufar Dalibaevna Djuraeva \\ Candidate Of Historical Sciences, Associate Professor, Head Of The Department Of History Of \\ Uzbekistan. Uzbek State University Of World Languages, Uzbekistan
}

\title{
ABSTRACT
}

The article examines women's problems - the status of women in the family and society, protection of their legitimate interests, employment, protection of motherhood and childhood, increasing the status of women in society in the years of independence, protection of their rights and interests. , labor. and improving living conditions has become one of the priorities and goals of public policy, and it is scientifically based that the problem of treating women has risen to the level of public policy and strategy. The factors determining the relevance of the topic are analyzed. The article highlights the attitude towards women in the renewed Uzbekistan, the essence of the state policy in the field of guardianship, aimed at comprehensive support of women. It is known that in recent years in the field of history, social philosophy, law, economics, pedagogy, such issues as treatment of women, gender equality, protection of the rights and interests of women, ensuring their social protection and employment, participation of women in internal and external migration have been considered. The scope of special research work is expanding. Problem-chronological, comparative-analytical methods of the occurrence of socio-historical events are based on a methodological approach that allows the synthesis of objectivity, accuracy and development, linking history and modernity, ensuring the unity of theory and practice, a theoretical and methodological basis. research based on the formation of such scientific principles as interdependence, structure, development in development.

\section{KEYWORDS}


State, society, politics, women, history, reforms, globalization, social status, social activism, welfare policy, law, interests, freedom, methods, historicity, objectivity, systematization.

\section{INTRODUCTION}

The problem of women is a complex of social issues related to such issues as the status of women in the family and society, protection of their legitimate interests, employment, protection of motherhood and childhood.

Over the years of independence, raising the status of women in society, protecting their rights and interests, improving working and living conditions has become one of the priorities and goals of state policy, and the issue of treating women has risen to the level of state policy and strategy [1].

In this regard, it is advisable to cite the following views of President Sh. Mirziyoyev: "In the current era of globalization, the protection of the rights and freedoms and legitimate interests of women is becoming increasingly important. In particular, an increase in the socio-economic, political and legal activity of women is becoming a requirement of the times "[2].

The Action Strategy for five priority areas of development of the Republic of Uzbekistan for 2017-2021 defines the following functions: to increase the socio-political activity of women, to strengthen their role in the state and society, to ensure the employment of women, graduates of professional colleges, and also to involve them in entrepreneurial activities, further strengthening the foundations of the family.

While the level of morality of any society is determined by the attitude towards women, from the first years of independence, under the leadership of the state and government, Uzbekistan pursued a policy of caring for the full support of women. In this regard, it is appropriate to quote the following words of President Sh. Mirziyoyev: "Our people have always shown great respect for the Mother of God and women. Respect for women is, first of all, an expression of respect for the family, for the future of society.

From this point of view, the wise saying, "The cultural level of any society on earth is determined by its attitude toward women," certainly has a deep meaning. "[2]

The relevance of the topic can be justified by the following factors:

First, while history has been determined by states for hundreds of years, in the twentieth century it has been replaced by totalitarian ideology. At the turn of the 21st century, world politics is determined by the clash of cultures. This puts on the agenda as a scientific need to study the place and role of women in cultural processes, who have played a unique role in the history of national culture, which is an important factor in the policy of spiritual stabilization of society in today's era of globalization.

Secondly, it is important to study the activities of women in the field of spirituality and education, emphasizing the unique role of women teachers in the revival of the national spirituality of the Uzbek people over the years of independence, its development in accordance with modern requirements. 
Third, in today's dangerous information age, in the complex era of globalization, the current problems in the field of spirituality, the protection and promotion of the spirituality of our people, especially the protection of the hearts and minds of the younger generation from various harmful ideas and ideologies. The analysis of the activities of women in the field of spirituality and enlightenment shows that it is not only theoretical but also of practical importance.

Fourth, the responsibility of Uzbek women "to preserve the national eastern spirituality and continue it at a higher level, on a modern basis" determines the relevance of the chosen topic.

\section{METHODS}

The article presents the data studied on the basis of generally accepted methods of analysis. The theoretical and methodological basis of studying the role and role of women of Uzbekistan in the cultural and educational processes of the $\mathrm{XX}$ century were also analyzed.

\section{RESEARCH RESULTS}

As a result of the state policy of caring for women and comprehensive support for women in the renewed Uzbekistan, the following results have been achieved: "Today .... women make up $45 \%$ of the employed population of the country, ... .. the proportion of women in the system has reached 33 percent. About 1,500 women across the country hold various leadership positions. In particular, our organizational and initiative sisters work effectively as governors in 6 districts, deputies and consultants in hundreds of regions. Manages large enterprises, banks and companies, business entities. To further increase such a great potential, strengthen their participation in government and society, a reserve of more than 6,000 active women has been formed "[3].

Because a society can have an ideal direction in its development only if women are actively involved in science, technology, production and management in all spheres of social life. Therefore, in the era of globalization and the clash of civilizations, the problems of further development of the place and role of women in modern society, where development is impossible without the participation of women, are being raised.

Now experts in human development believe that without studying the role of women in all spheres of human society, it is impossible to fully understand the historical path and development traversed by humanity. In particular, pay attention to the opinion of the researcher Gisella Bock: "In the past, the experience, activities and spheres of life of women were also ignored, because they did not represent historical value. However, the history of women "should be considered as general as the history of men, ... because it applies not only to half of humanity, but to all" [4]. In this regard, Joan Kelly said: "We are not talking about the return of women to history, but above all about the return of history to women. Although such attention is paid not only to women in history, but also to the history of women, it is also a special kind of history, that is, the history of women around the world as women "[5].

It is known that in recent years in the fields of history, social philosophy, law, economics, pedagogy, issues such as the treatment of 
women, gender equality, protection of women's rights and interests, ensuring their social protection and employment, women's participation in internal and external migration. The scope of dedicated research work is expanding. Problem-chronological, comparative-analytical methods, the emergence of socio-historical events based on a methodological approach that allows the synthesis of objectivity, accuracy and development, linking history and modernity, ensuring the unity of theory and practice, the theoretical and methodological basis of research, interdependence in development, structure, scientific principles such as development.

In the coverage of historical data, facts, events and happenings, special attention was paid to the principle of logical generalization and historical comparison. Evidence of events and phenomena, logical generalization and ethnopsychological comparison of the covered data, socio-psychological survey, problematic ethnological and cultural analysis methods were also used in the study of the topic.

The main methodological principles, such as historical, objective, systematic, which were widely used in writing the research work, were also noted during the administrativecommand system, and in the socio-political sciences they were presented as basic methodological principles. However, their goal was different, and these principles were aimed at achieving the political goals of the communist ideology of the "red empire". Under the dictatorship, historical sources were required to be covered not from an objective point of view, but from the point of view of a predetermined Marxist-Leninist methodology and party decisions. Adherence to the motto "partisanship of science" was the "sacred duty" of every scientist. Therefore, such principles were far from fulfilling the selected problems in a scientifically complete and objective manner.

Under the conditions of independence, the situation changed radically, and as the abovementioned scientific principles were free from the political tricks of communist ideology, it began to serve the social sciences. The theoretical and methodological basis of research is also determined by the dialectical method of knowledge, the national idea and the universal principles of scientific thinking.

Is of great importance for the methodological basis of the works of the First President of the Republic of Uzbekistan I. Karimov and President Sh.M. Mirziyoyev. Important theoretical and methodological ideas expressed in the works, especially the positive attitude of women to the issues of increasing the activity of women in society, the role and place of women in social, spiritual and cultural life, are of great theoretical and scientific importance. At the same time, the laws adopted by the Oliy Majlis of the republic, based on the Constitution of the Republic of Uzbekistan, strengthening the role of women in the spiritual sphere of society, programs developed to protect the family, motherhood and childhood play an important role. important role. Articles 46, 63, 66 of the Constitution of the Republic of Uzbekistan and special laws provide legal guarantees for increasing the social activity of women and ensuring the stability of the family.

\section{CONCLUSIONS}


In the conclusion, it should be emphasized that methodology is a theoretical basis that determines the main goal of historical research, which can be assessed as a strategy of historical research. The methodological, ideological and theoretical basis of historical research has always been determined by the interests of a particular society, the leading social forces in it. Because of this, historical science serves the main conceptual goals of politics, social structure or movement, government, and so on.

\section{REFERENCES}

1. Decree PF-4947-conli "On the Strategy of further development of the Republic of Uzbekistan" dated February 7, 2017, PF-February 2, 2018 "On measures to radically improve the activities in the field of support of women and strengthening the institution of the family" Decree No. 5325, Presidential Decree PQ-4235 of March 7, 2019 "On measures to further strengthen the guarantees of women's labor rights and support entrepreneurship", Decree of September 2, 2019 "On measures to further strengthen the guarantees of women's labor rights and support entrepreneurship" Law No. ZRU 561 "On protection from violence" and ZRU 562 "On guarantees of equal rights and opportunities for women and men" // lex.uz

2. Speech of the President of the Republic of Uzbekistan Shavkat Mirziyoyev at the twentieth plenary session of the Senate of the Oliy Majlis // 22.06.2019
3. Speech by Shavkat Mirziyoyev at the ceremony on the occasion of March 8 International Women's Day // Shavkat Mirziyoyev awarded a group of women on the occasion of March 8 International Women's Day - Daryo

4. Chrestomathy of the course of the basics of gender research. -Tashkent: Uzbekistan, 2003. -P. 367

5. Chrestomathy of the course of the basics of gender research. -Tashkent: Uzbekistan, 2003. -P.371

6. Ziyoev $\mathrm{H}$. History is a mirror of the past and the future. - Tashkent: 2000. P.273.

7. Dalibaevna, N. D. (2020). THE PLACE AND ROLE OF WOMEN IN SOCIETY IN THE PRE-ISLAMIC PERIOD. INTERNATIONAL JOURNAL OF DISCOURSE ON INNOVATION, INTEGRATION AND EDUCATION, 1, 5865.

8. Djuraeva, N. D. (2019). Study of issues of attitude to the place and role of women of Uzbekistan in society in the XX century. Academia Open, 1(1).

9. DJURAEVA, N. Bağımsızlık Döneminde Dini Değerleri Yeniden Kazanma: Gelenek, Din, ve Kadının Sosyal Önemi. Motif Akademi Halkbilimi Dergisi, 7(13), 243-248.

10. Джураева, Н. А. (2017). Отношение к женщине в воззрениях джадидов Туркестана. Academy, (10 (25)). 